\title{
Archaeological Analysis of Shell Middens in the Beagle Channel, Tierra del Fuego Island
}

\author{
JORDI ESTEVEZ ${ }^{a, *}$, ERNESTO PIANA $^{\mathrm{b}}$, ADRIAN SCHIAVINI $^{\mathrm{b}}$ AND \\ NURIA JUAN-MUNS ${ }^{a}$ \\ a Department de Antropologia Social i Prehistoria, Universitat Autonoma de Barcelona, \\ 08193 Bellaterra, Spain

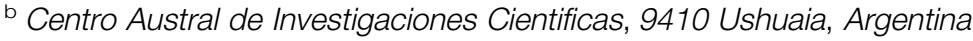

\begin{abstract}
An archaeological programme beginning in 1993, in the Beagle Channel, aims to describe the long-term record of maritime faunal exploitation, and relate it to the environmental record. Results from quantitative analysis of remains from a series of shell midden excavations indicate a remarkably stable and resilient marine biota over the last 6500 years. Only in the previous century have there been changes in fauna, which might correspond to recent global warming. Copyright (C) 2001 John Wiley \& Sons, Ltd.
\end{abstract}

Key words: Tierra del Fuego; Beagle Channel; shell middens; seals; fish; environmental change

\section{Introduction}

Tierra del Fuego lies at the southernmost extremity of the Americas, where the waters of the Pacific, Atlantic and Antarctic Oceans converge and produce a rich marine animal community of sea mammals, fish and birds. In contrast, the land animals are relatively few, and typical of Patagonia (e.g. the guanaco, Lama guanicoe, and kelp goose, Chloephaga sp.). The land is covered in Nothofagus forest, and the high annual rainfall washes nutrients to the shore, where they support a high biomass of mussels which are able to survive because the sea does not freeze in winter. A rich ethnographic record describes the lifeways of the Yamana, 'Canoe' Indians, in this region. Highly mobile, they survived until shortly after the settlement of Europeans by gathering mussels, fishing and hunting sea-lions. Archaeological investigations in this area have been designed to discover whether there had

\footnotetext{
* Correspondence to: Department de Anthropologia Social i Pre historia, Universitat Autonoma de Barcelona, 08193 Bellaterra, Spain.
}

Copyright (C) 2001 John Wiley \& Sons, Ltd. been significant change in subsistence patterns during the Holocene.

\section{Archaeological research programmes}

Excavations conducted since 1975 at shell midden sites, such as Lancha Packewaia, Tunel I and Shamakush I and X (Figure 1), describe an archaeological record extending from the 17th century to 6500 BP which documents extensive exploitation of marine resources (Orquera \& Piana, 1987). Faunal analysis demonstrated the

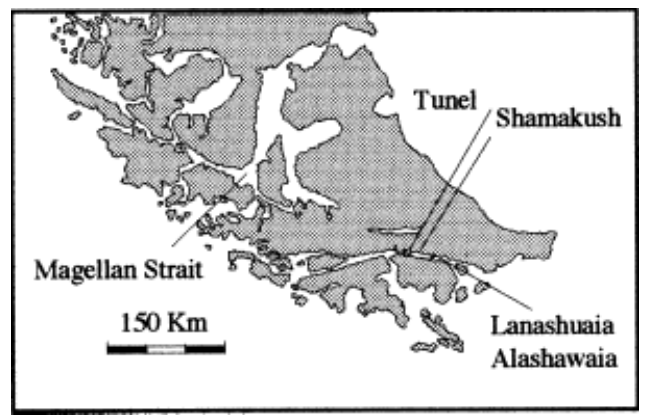

Figure 1. Map of Tierra del Fuego and localization of mentioned sites. 
resilience of the main taxa and the stability of the subsistence patterns, as well as the importance of sea-lion hunting (Schiavini, 1990, 1993).

From 1986, a project on the contact period has collated much of this historical information, and has, especially, been interested in the impact of European marine mammal hunting on the older subsistence patterns (Piana et al., 1992; Orquera \& Piana, 1995a).

Since 1993, a European Union project, run by Spanish and Argentinean archaeologists, entitled 'Marine resources at the Beagle Channel: an archaeological perspective' has aimed at constructing a 6000 year long climatic record from oxygen-isotope data, contained in stratified deposits of mussel shell, in order to contrast this information with the long-term faunal record. It is the results of this project which are described here.

The sites chosen for analysis were Tunel VII, Lanashuaia and Alashawaia. The first is close to the oldest coastal site in the eastern Yamana region, while the other two lie $80 \mathrm{~km}$ to the east, at the periphery of the region once occupied by Canoe people. The research also involved a complete archaeological survey on the east-central coast of Tierra del Fuego, including GPS positioning of 131 sites, gathering of environmental context information, stratigraphic sampling and subsequent radiocarbon dating.

The initial hypotheses of this project included the possibility that the dislocation of Yamana subsistence and their cultural extinction had been caused by European over-hunting of marine mammals. Alternatively, there may have been a significant change in ecological conditions caused by historical, human-induced, climatic change. A third possibility was that climatic and faunal changes were within the range of other natural changes in the past.

The project had some important advantages. The Beagle Channel shell middens have an extraordinarily well-preserved and very complete faunal record, from micro-invertebrates up to whales, and the formation processes of these sites had already been studied in some detail by Orquera \& Piana (1992). During the course of the project, experiments were undertaken to measure the possible taphonomic losses in the faunal record, an enterprise made easier by the relatively undisturbed local landscape.

\section{Modern fauna}

A systematic survey of marine resources was carried out in order to construct a modern and comparative database. Included in this was a study of the sea-lion and seabird colonies on the southern coast of Isle Grande de Tierra del Fuego and Staten Island. Results from 410 transects show that the most abundant birds in the Beagle Channel are the imperial shag, blackbrowed albatross and southern black-backed gull. The Magellan penguin, Magellan gull and South American tern occur in isolated concentrations while the Magellan diving-petrel and great skua are dispersed. There are also shoreline species, such as the kelp goose and steamer duck. Seasonal movements are important. The South American tern, great skua and buffnecked ibis abandon the Beagle Channel in winter and there are lower numbers of kelp goose and Magellan gull, but the sooty shearwater and rockhopper penguin arrive in autumn, and the Antarctic fulmar in winter.

There is also seasonality in fish availability (Lloris \& Rucabado, 1991; cf. Juan-Muns, 1992). Clupeidae peak in numbers during summer and again in late winter and this occurs to a lesser extent in Macruronus magellanicus. The abundant Eleglynops maclovinus and Nototheniidae can be fished all year. Some taxa found in middens, such as Gempylidae, are seldom found in the channel today. Fish capture data (Lloris \& Rucabado, 1991) for an area near Ushuaia (close to Tunel and Lancha Packewaia) and another at Cambaceres Bay (near Lanashuaia and

Table 1. Number and species of captured fish on two Beagle locations

\begin{tabular}{lcc}
\hline Taxa and capture points & Cambaceres & Ushuaia \\
\hline Patagonotothen tessellata & 20 & 40 \\
Macruronus magellanicus & 0 & 0 \\
Patanotothenia magellanica & 10 & 12 \\
Clupeidae & 10 & 0 \\
Eleglynops maclovinus & 40 & 448 \\
Gempylidae & 0 & 0 \\
Altrii & 20 & 40 \\
\hline
\end{tabular}

Int. J. Osteoarchaeol. 11: 24-33 (2001) 
Alashawaia) are shown in Table 1. Data were also collected on the productivity of shorelines, measuring the occurrence of shellfish species and their size and $\mathrm{MNI} / \mathrm{m}^{2}$.

\section{Methodological considerations}

Archaeological experience since 1975 has led to improvements in excavation and recording techniques. It has been possible to identify very short episodes of midden deposition and, therefore, to generate a fine-scaled record of people's activity. Stratigraphical information can be checked by micromorphological, biochemical and spatial analysis, including refitting and usewear analysis of lithic and bone items (Estévez \& Vila, 1995). As a result, it was possible to detect ten occupations at Tunel VII, and three at Lanashuaia. Only the last occupation was excavated at Alashawaia. These excavations were each more than $50 \mathrm{~m}^{2}$, and they revealed the remains of reoccupied huts, each about 9 $\mathrm{m}^{2}$, in an area surrounded by piles of refuse (Wünsch, 1995).

\section{Shell midden sampling}

Shell middens have very rapid rates of sedimentation, and there are significant differences in the distribution of contents within the same occupation units (see Table 2). At Tunel VII, for example, fish bone numbers varied from 44 to $646 / \mathrm{dm}^{3}$, and there are also variations in relative frequencies amongst the remains, with the ratio of fishbone to all other bones varying from 11 to $367 / \mathrm{dm}^{3}$. Another issue is the variation in time amongst superimposed stratigrapic units. In some strata, layers may be close together in time, but in others, far apart. Quantitative analysis based on column samples would, therefore, produce only a poor basis for comparison. In Tunel VII, for example, the density of Mytilus sp. varies form 30.6 to $280.4 / \mathrm{dm}^{3}$. One control column sample gave a mean of 75.3, another $174.3 / \mathrm{dm}^{3}$ (Orquera \& Piana, 1995b). In Tunel $\mathrm{I}$, the density of fishbones varied from 54 to $486 / \mathrm{dm}^{3}$. In the light of this variability, column sample has revealed it is only adequate for a rough qualitative approach. Zooarchaeological analysis was conducted, therefore, extensively on the sites Tunel I, Lancha Packewaia, Shamakush I and X, Tunel VII, Alashawaia and Lanashuaia.

Our procedure was as follows. The individual faunal remains of birds, seals, whales and terrestrial mammals were classified taxonomically. A different method was used to quantify fish and mollusc remains because of their abundance. We established experimentally the volume of sediment required in order to obtain a statistically significant sample of remains. This was done by taking all the sediment from different stratigraphic subunits by 0.51 samples, and

Table 2. Density variation in shell midden deposits and total amount of remains calculated

\begin{tabular}{|c|c|c|c|c|c|c|c|}
\hline Sites & Tunel I & Shamakush X & Shamakush I & Lanashuaia & Tunel VII & Tunel VII & Alashawaia \\
\hline Layers & Layer D & Four trenches & $\mathrm{C}-\mathrm{F}$ & C5 & Intermediate & Total layer B & $\begin{array}{l}\text { Last } \\
\text { occupation }\end{array}$ \\
\hline Pinnipedia & 67516 & 10 & 1232 & 69 & 693 & 8928 & 12 \\
\hline Fishes & 51192 & 4000 & 122320 & 7076 & 104937 & 2049164 & 13 \\
\hline Cetacean & 858 & 59 & 201 & 1023 & 43 & 771 & 2 \\
\hline Guanaco & 5486 & 11 & 1332 & 23 & 18 & 117 & 8 \\
\hline Birds & 32651 & 179 & 561 & 41 & 1366 & 13704 & 116 \\
\hline Total & 617703 & 4258 & 125646 & 7219 & 107057 & 2072683 & 151 \\
\hline Volume $\mathrm{m}^{3}$ & 40.7 & 5 & 8.8 & 1.677 & 0.668 & 1228 & Only surfaces \\
\hline Molluscs & - & - & - & 453013 & 12500 & 3345563 & - \\
\hline $\begin{array}{l}\text { Excavated } \\
\text { surface } \mathrm{m}^{2}\end{array}$ & 150 & 16 & 16 & 100 & 32 & 72 & 92 \\
\hline
\end{tabular}

Regular font: Number of remains recovered.

Italics: Number of remains calculated from sample.

Bold: Sum of remains recovered and calculated.

Copyright (C) 2001 John Wiley \& Sons, Ltd.

Int. J. Osteoarcbaeol. 11: 24-33 (2001) 


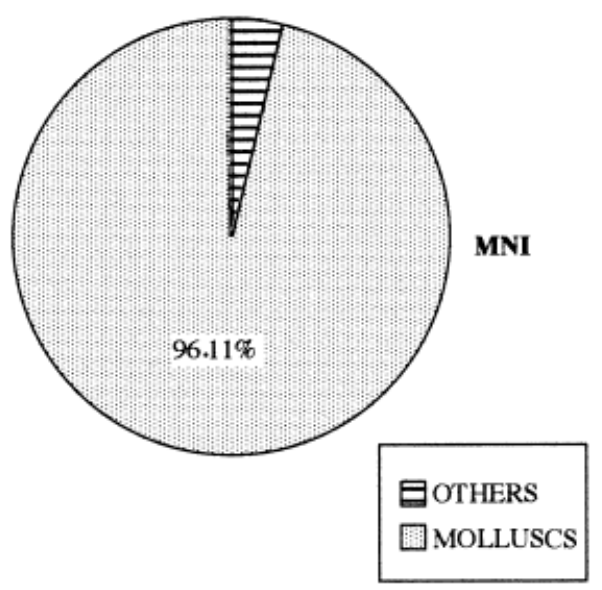

Figure 2. MNI percent graph, including molluscs in Tunel VII.

passing the data through probability algorithms to model the representative sample strategy and its margin of error. For our sites, the strategy required 0.51 samples of homogenized, unsieved sediments from each small stratigraphic unit. The samples were processed in the laboratory by trained personnel, who counted and weighed the remains by type, and extrapolated to the measured volume for each stratigraphic unit. This enabled the calculation of faunal remains for each of the sedimentary units.

Considering that the meat of one whale of 30 tonne weight is equal to 6 million mussels, MNI was not a sufficient measure of quantity. It is demonstrated that remains of large animals were shared among households (Estévez \& Martínez, 1998). Consequently, we estimated the meat weight of large animals according to the number of remains of each species. The small animal remains were quantified by multiplying the measured quantities of each type from the 0.51 samples by the total volume of sediments for the unit in which each sample occurred. MNI was used only as a means of evaluating relative resource use within occupation units of fully excavated sites (see Figures 2 and 3).

In addition to quantification of midden, we were concerned about the ability of scavengers, such as foxes, birds and domestic dogs, to remove or damage material from the sites. There was very little evidence in our sites of this kind of disturbance.

Copyright (C) 2001 John Wiley \& Sons, Ltd.
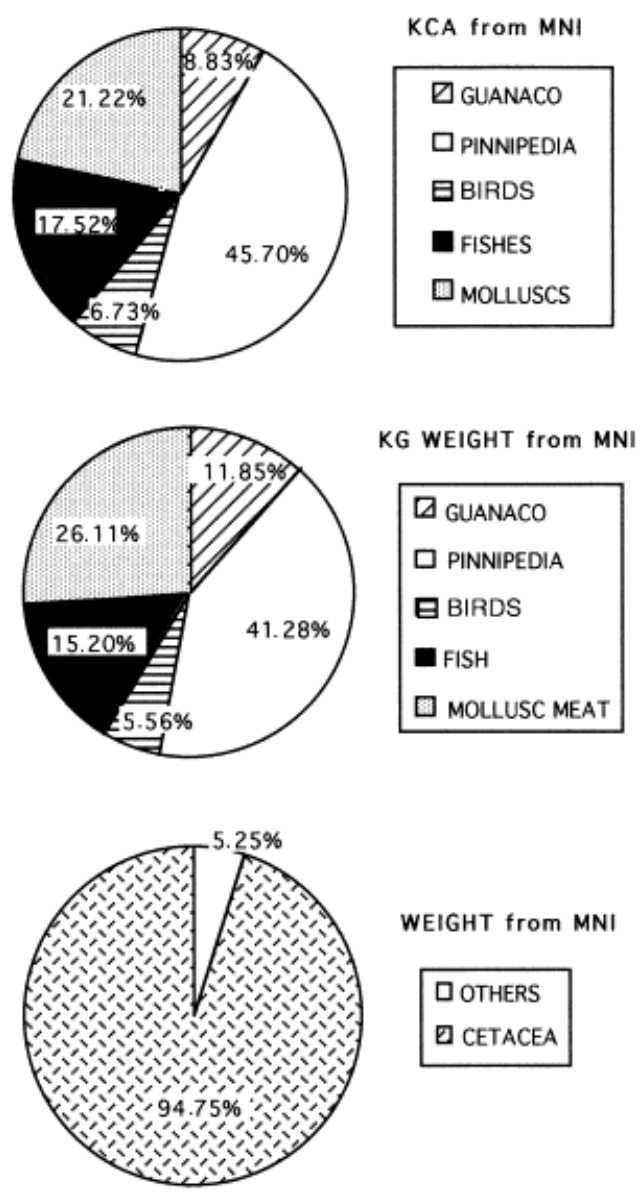

Figure 3. Calories and weight contribution percent calculated from $\mathrm{MNI}$ without cetacean and meat weight, taking into account the cetacean.

\section{Resource exploitation since $6500 \mathrm{BP}$}

The distribution of excavated components in time is as follows. Tunel I, layer D is the most ancient coastal stratum in Tierra del Fuego (6140-5700 BP). Next is Lancha Packewaia, ancient component (4300 BP), followed by Shamakush I (1200 BP) and X (500 BP). Lanashuaia, Alashawaia and Tunel VII belong to the European contact period. The sites have been occupied several times in different seasons, and the sum of the occupations covers more than a full year in each case. Even the later sites have been occupied for some time. Tunel VII, having one of the shortest occupation, contains ten occupation episodes over a time span of 80 years (Piana \& Orquera, 1995).

Int. J. Osteoarchaeol. 11: 24-33 (2001) 


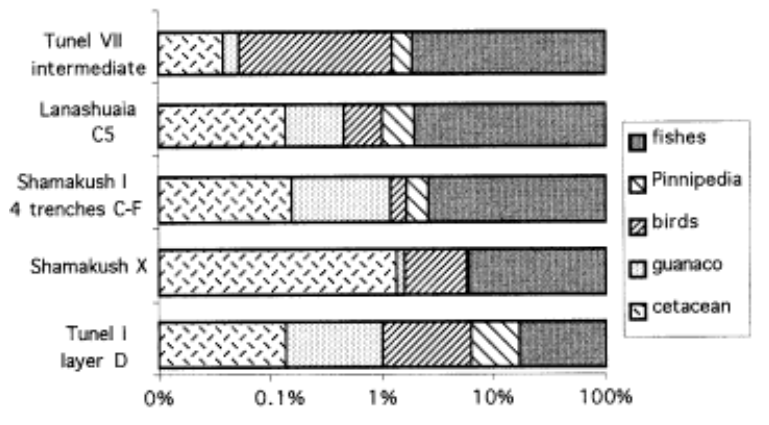

Figure 4. Log ratio bar histogram on the percentage of NISP of vertebrate taxa.

There are no changes in the qualitative composition of fauna in the entire period, indicating a considerable resilience in the exploited resources (Table 2, Figures 4-7). Sea-lions, whales and guanaco are always present. Amongst birds, the cormorant, penguin and albatross are the most frequent taxa, and steamer ducks and kelp geese are also common (Figure 8).

Essentially, the same exploitation of fish is apparent throughout. These include Nototbeniidae and, particularly, Patagonotothen tessellata and Patagonotothen magellanica. Other fish represented, such as Macruronus magellanicus and Sprattus fuegensis occur in summer and autumn. Gempylidae, including Thyrsites atun, occur quite commonly in the archaeological deposits, but rarely occur in the channel today. Conversely, Eleglynops maclovinus is an anadromous species frequent in present day catches, but scarce in the archaeological record. This suite of species indicates individual fishing, scavenging of beached species, and the use of baskets from canoes. Molluscs and crustaceans, among other invertebrates, were also common elements of the midden.

Elsewhere, we have argued that the main subsistence staples were sea mammals, especially pinnipeds, followed by sea birds and guanaco (Piana, 1984; Schiavini, 1993). However, the molluscs are the largest midden component by MNI (Figure 2), and are dominanted by mussels, and in a few units, by limpets. On the other hand, the cetaceans would be the main contributors of calories (Figure 3). Consideration of vertebrate NISP provides a better view of differences between samples (Figure 4). Fishbones are the most abundant vertebrate remains, with relative frequencies of over $80 \%$, and there is a low tendency towards increasing abundance over time (Figure 4 ; Table 2). There is no convincing explanation for this in terms of the fishing possibilities near each site. It is possible that the chance exploitation of massive summer strandings of Clupeidae and their predators accounts for some of the variation, but it does not explain all

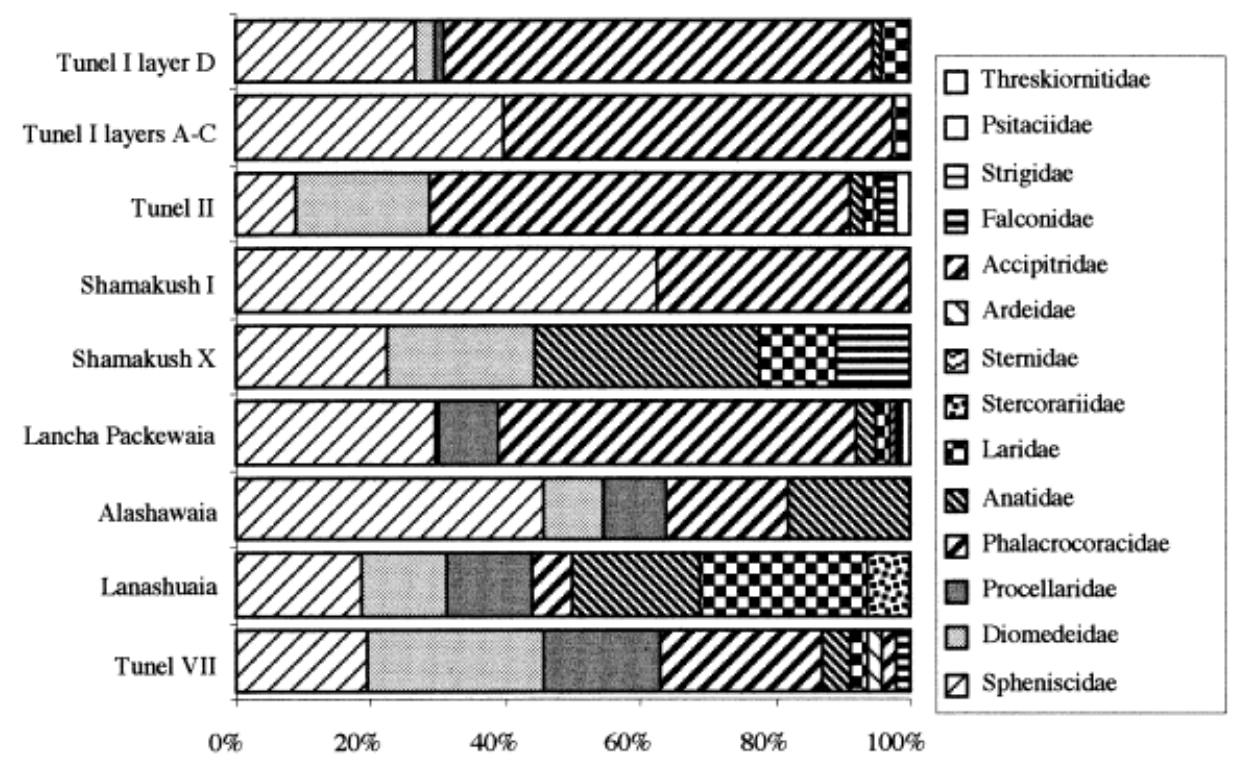

Figure 5. Relative frequencies for the main bird taxa in the studied sites. 


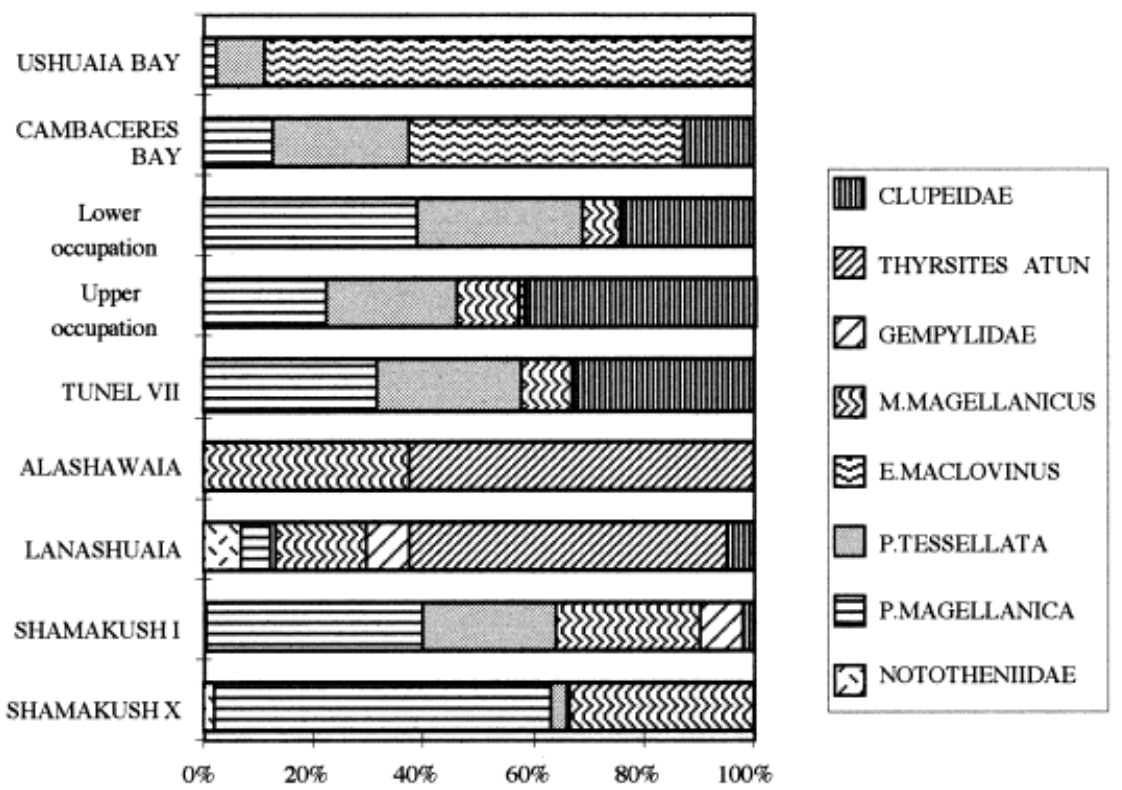

Figure 6. Relative frequencies for the main fish taxa in the studied sites.

of the differences that cross layers and seasons in the data. Sea lions are most abundant in the oldest site.

Shamakush, site $\mathrm{X}$, is characterized by a high level of cetacean bone. Shamakush, site I, has more guanaco bone than Lanashuaia, despite the fact that the local environment of the latter site provided better shelter for this species. The Tunel VII complex has noticeably high quantities of bird bone, as does Alashawaia. Both sites are located close to sea bird colonies. At Alashawaia, the dominant taxa are penguins, and the site is located next to the most important penguin colony in the area. Cormorants are dominant at Tunel VII (also nearby Tunel I, II and Lancha Packewaia), located closest to the modern colonies of these birds in the channel. In other sites, there is a similar correspondence between the modern bird distribution and the sites. For example, Anatidae are common at Shamakush, and in the Cambaceres area. The distribution of bird taxa in the archaeological sites is shown in Figure 5 and Table 3. The situation is different with regards to fish. There is a correspondence between taxa of geographically close sites. Nototheniidae are dominant in the two Shamakush sites, Gempylidae are dominant at Alashawaia and Lanashuaia, and shore fishes and
Clupeidae at Tunel sites. This distribution does not correspond with environmental expectations. It could be expected that Clupeidae would strand more frequently on the shallow coast near Shamakush than on the steeper coast at Tunel. The abundance of Thrysites atun, and the presence of Macruronus magellanicus and Clupeidae on the Lanashuaia site indicates more frequent fishing in the open channel than in the nearby river mouth. The low frequency of Nototheniidae indicates a scarcity of winter fishing, possibly because of the abundance of guanaco in this area during winter. Tunel VII indicates both summer and winter fishing for all species.

\section{Hunters or fishers: subsistence strategies}

Fishing was a very important activity throughout the archaeological sequence, as it is stated in the ethnographical record (Orquera \& Piana, 1995a), and it must have accounted for much of the subsistence effort (Figure 7), considering the means used to catch the species concerned (Juan-Muns, 1994). There is some evidence that the time spent in fishing increased recently. For example, on two occupation episodes at Tunel VII (Estévez et al., 1995) there are remains of 2676 fishes and 125000 mussels, compared with 


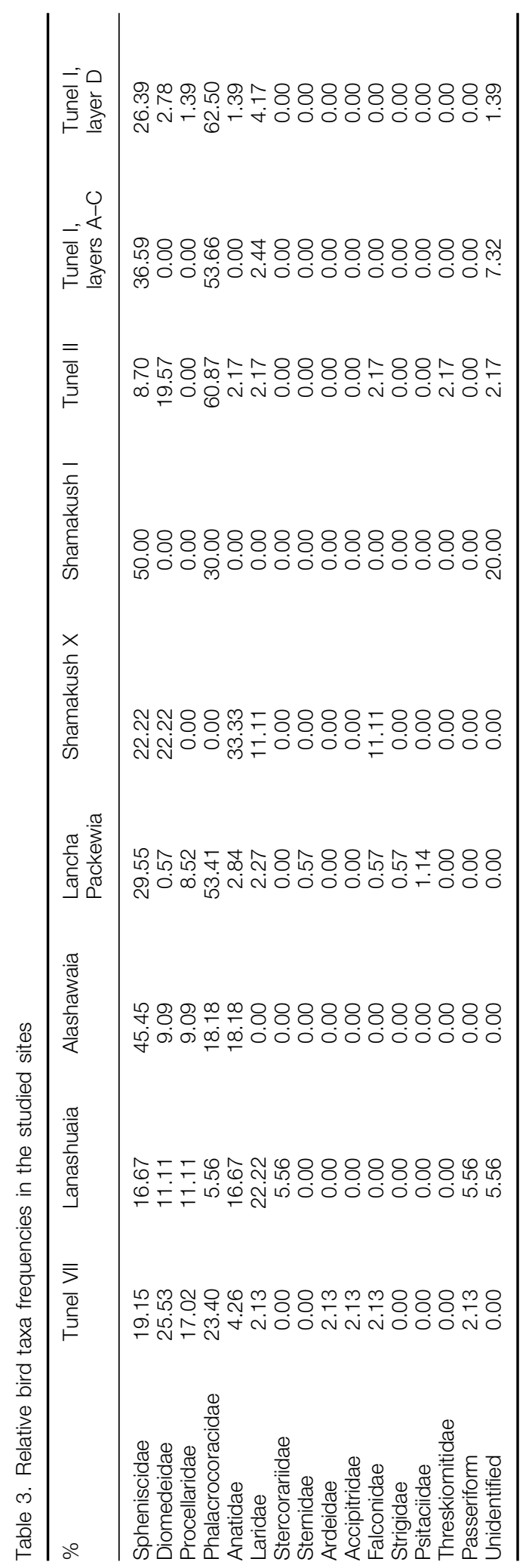

Copyright (C) 2001 John Wiley \& Sons, Ltd.

Int. J. Osteoarcbaeol. 11: 24-33 (2001) 


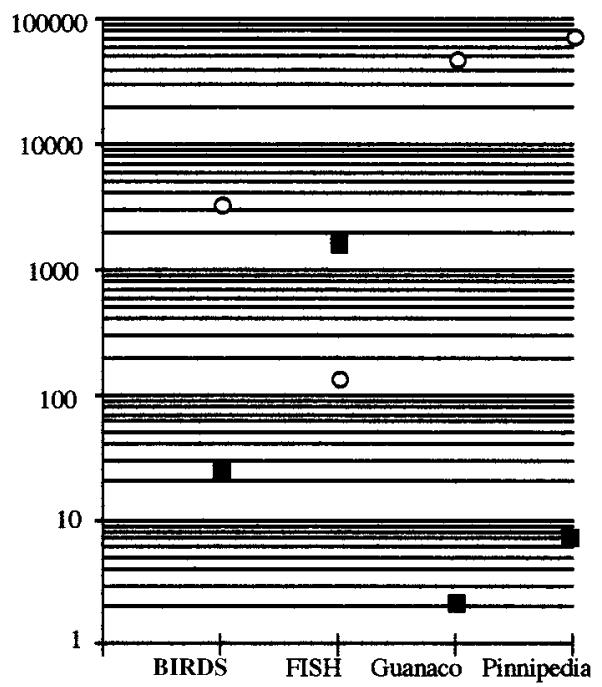

Figure 7. Number of extracting activities (black square is the number of catching actions and circle is the resulting kilocalories/actions) on an occupation episode on Tunel VII, showing the high dedication to fishing. Kilocalories calculated the minimal number of individuals and estimated number of catching actions.

only 43 birds, some pieces of a whale and dolphin and parts of seven sea-lions. Yet, does this represent an increase in fishing or a reaction to the depletion of sea-lions by European overhunting? The previous stability in biotic conditions in Tierra del Fuego suggests the latter explanation, and there is evidence that sea-lion hunting was particularly scarce at the beginning of this century. Nevertheless, this case is insufficient to sustain the argument of a dramatic shift from sealing to intensive fishing. It is possible that there was some social resistance to adopting subsistence activities in the light of EuroAmerican sea-lion depletion, although it would have been possible, and relatively easy, to increase fishing. Seal harpooning was a male activity and important for social display, whereas fishing from canoes was a discreet, women's activity (cf. Barceló et al., 1994). We can rule out the possibility of a change in ethnic identity because of the demonstrably continuous archaeological sequence, and also the DNA studies of Garcia et al. (1988), although there are some changes in the technology which do not correlate to those in the fauna (Orquera \& Piana, 1995a).

Copyright (C) 2001 John Wiley \& Sons, Ltd.
Sites linked closely in time often exhibit different faunal complexes, reflecting in part the characteristics of local environments, but there is less variation in technological remains. The results of faunal analysis at Tunel VII, Lanashuaia and Alashawaia allow a comparison amongst three contemporary sites. Alashawaia's faunal assemblage, corresponding only to the last occupation of the site, shows a dominance of birds, followed by guanaco and fur seal, and it also has considerable remains of sheep or goat bones. At Tunel VII and Lanashuaia, fur seal and birds are important, but there are more cetacean bones in the latter site (Figure 4). Amongst the birds, Phalacrocoracidae are dominant at Tunel VII, and Stercorariidae at Lanashuaia. There is also a variation in faunal composition between different occupation episodes of the same hut, as in Tunel VII, where the incidence of fishbone is highly variable, and may reflect a short episode of beaching.

\section{Euro-American impact on marine resources and recent climatic change}

Tierra del Fuego appears globally to be an unchanged land, but some differences appear

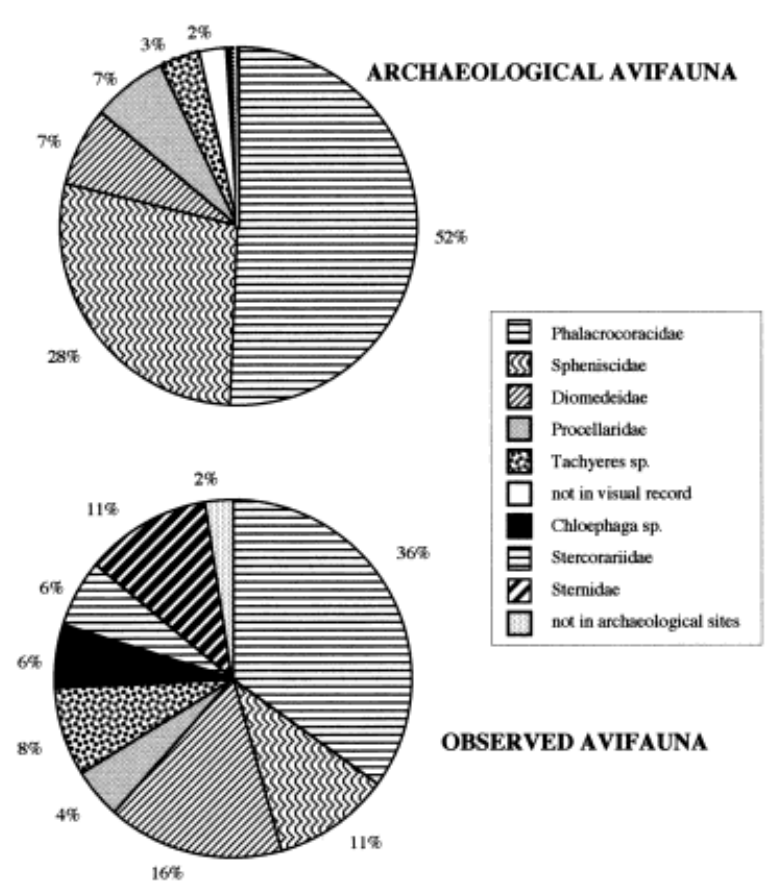

Figure 8. Comparison between past hunted taxa and today's counted birds. 
comparing current biocenose with that represented in the subfossile record.

Despite selective hunting the abundance relationship of fur seal to sea lion is, at ten to one today, the same as in the archaeological evidence, and according to historical data about the same as at the time when Euro-American hunting began. This, possibly, reflects that overhunting of the fur seal up until the middle 19th century was followed by frequent hunting of the sea lion until the mid-1900's (Sielfeld, 1978; Schiavini, 1990, 1993; Crespo et al.). There is also a remarkable similarity between the proportions of birds hunted prehistorically and those counted now in the channel (Humphrey et al., 1970; Parmelee \& Rasmussen, 1994; Schiavini \& Yorio, 1995). These few differences are easy to explain, such as the depletion of penguins by hunting and egg collection in the recent past.

The most interesting difference is the contrast between archaeological data and the composition of recent fish catches. Only a small number of species obtained in the channel today are present in zooarchaeological samples, despite the fact that $45 \%$ of fish biomass is concentrated near the coast, where it was accessible to prehistoric fishing. In both sets (Table 1) of recent catch data, E. maclovinus is the dominant species, but it is scarce in the archaeological record. As the modern fish were captured using aboriginal techniques, technology cannot be the explanation. Nor is a seasonal explanation plausible, as E. maclovinus was captured all year round. Perhaps this phenomenon can be explained by social practice.

In the archaeological record, Thyrsitis atun is common in samples of up to 100 years old, yet it is rare in Beagle Channel waters today. Environmental change seems the only probable explanation. Some changes in vegetation, such as the disappearance of Maytenus magellenica, may also have an environmental explanation, but could be a result of selective felling, or the introduction of domestic animals.

Isotope analysis carried out by Obelic et al. (in press) disclosed the first evidence in subantarctic sea waters of a warming period comparable in age with the Medieval climatic optimum, and of sea surface temperatures related to the Little Ice Age. However, the oxy-

Copyright (C) 2001 John Wiley \& Sons, Ltd. gen isotope data emphasize the high abiotic stability of Beagle Channel sea surface temperatures during the last 6000 years. These remain within a range of $\pm 1.16^{\circ} \mathrm{C}$. In contrast, modern sea surface temperatures are $1.7^{\circ} \mathrm{C}$ higher than any reached previously.

\section{Conclusion}

The archaeology of shell middens can be very useful in providing a temporal dimension for understanding modern ecosystems, and for assisting research into climatic change. Our evidence indicates that since the early Holocene opening of the Beagle Channel, the marine ecosystem has been highly stable and resilient, at least for the species represented in the archaeological record. However, there are some signs of faunal change in the most recent past, which might reflect increasingly warm sea surface temperatures.

\section{Acknowledgements}

This study contains part of the conclusions of the European Union research project CT-93007.

\section{References}

Barceló JA, Estévez J, Wünsch G, Pallarés M, Mora M. 1994. KIPA - a computer program to analyse the social position of women in hunter-gatherer societies. In Methods in the Mountains. Sydney University Archaeological Methods Series, No. 2, Johnson I (ed.). Sydney University Press: Sydney, Australia; $165-172$.

Crespo EA, Schiavini ACM, Pérez F. 1996. Distribución y abundancia de lobos finos Arctocepbalus australis en las costas de Argentina. In Séptima Reunión de Trabajo de Especialistas en Mamíferos Acuáticos de América del Sur. 22-25 October 1996. Viña del Mar, Chile.

Estévez J, Juan-Muns N, Martínez J, Piqué R, Schiavini A. 1995. Zooarqueología y antracología: estrategias de aprovechamiento de los recursos animales y vegetales en Túnel VII. In Encuentros en los conchales fueginos, Estévez J, Vila A (eds). CSICUAB: Bellaterra, Spain; 143-238.

Int. J. Osteoarchaeol. 11: 24-33 (2001) 
Estévez J, Martínez J. 1998. Archaeozoological Researches at the Beagle Channel, Argentina. Anthropozoologica 26: 237-246.

Estévez J, Vila A (eds). 1995. Encuentros en los conchales fueguinos. Universitat Autònoma de Barcelona and Consejo Superior de Investigaciones Científicas: Bellaterra, Spain.

Garcia C, Hernandez M, Turbon D. 1988. Cráneos yámanas y de otros aborígenes de La Tierra del Fuego en colecciones europeas. In Trabajos de Antropología, vol. XXI, no. 2. Universitat de Barcelona; $129-136$.

Humphrey PS, Bridge D, Reynolds PW, Peterson RT. 1970. Birds of Isla Grande (Tierra del Fuego). Preliminary Smithsonian Manual. University of Kansas Museum of Natural History: Lawrence, KS.

Juan-Muns N. 1992. La pesca com alternativa econòmica per als yamana, nómades canoers del canal Beagle (Tierra del Fuego, Argentina), PhD Thesis. Universitat Autònoma de Barcelona, Bellaterra.

Juan-Muns N. 1994. Fishing strategies in the Beagle Channel, Tierra del Fuego/Argentina: an ethnoarchaeological approach. Acbaeo-Icbtiological Studies. OFFA 51: 313-316.

Lloris D, Rucabado J. 1991. Ictiofauna del Canal Beagle (Tierra del Fuego), aspectos ecológicos y análisis biogeográfico. Publicaciones especiales del Instituto Español de Oceanografía. 8: Madrid.

Obelic B, Alvarez A, Argullós J, Piana E. in press. Determination of the Paleotemperature in Beagle Channel (Argentina) through stable isotope composition of Mytilus edulis shells. In Quaternary of South America and Antarctic Peninsula, Rabasa J (ed.). Balkema: Rotterdam.

Orquera LA, Piana EL. 1987. Human littoral adaptation in the Beagle Channel region: maximum possible age. In Quaternary of South America and Antarctic Peninsula 4. A.A. Balkema Publishers: Rotterdam, $133-162$.

Orquera LA, Piana EL. 1992. Un paso hacia la resolución del Palimpsesto. In Analisis espacial en la Arqueologia patagónica, Borrero LA, Lanata JL (eds). Ayllu: Buenos Aires; 21-52.
Orquera LA, Piana EL. 1995a. Tunel VII en la secuencia arqueológica del canal Beagle: Hipotesis y expectativas de los investigadores argentinos. In Encuentros en los conchales fueginos, Estévez J, Vila A (eds). CSIC-UAB: Bellaterra, Spain; 25-45.

Orquera LA, Piana EL. 1995b. Tunel VII: La excavación. In Encuentros en los conchales fueginos, Estévez J, Vila A (eds). CSIC-UAB: Bellaterra; 47-81.

Parmelee DF, Rasmussen PC. 1994. Status of birds in the Ushuaia Bay, Argentine Tierra del Fuego, in spring and summer. University of Kansas Museum of Natural History Occasional Papers, 168; 1-24.

Piana EL. 1984. Arrinconamiento o adaptación en Tierra del Fuego. In Antropologia argentina 1984. Editorial de Belgrano: Buenos Aires; 7-110.

Piana EL, Orquera LA. 1995. Tunel VII: La cronología. In Encuentros en los conchales fueginos, Estévez J, Vila A (eds). CSIC-UAB: Bellaterra, Spain; 105111.

Piana EL, Vila A, Orquera LA, Estévez J. 1992. Chronicles of Ona-ashaga: archaeology in the Beagle Channel (Tierra del Fuego-Argentina). Antiquity 66: 771-783.

Schiavini A. 1990. Estudio de la relación entre el hombre y los pinníperos en el proceso adaptativo humano al Canál de Beagle (Tierra del FuegoArgentina), PhD Thesis. Universidad de Buenos Aires.

Schiavini A. 1993. Los lobos marinos como recurso para cazadores-recolectores marinos: el caso de Tierra del Fuego. Latin American Antiquity 4: 346366.

Schiavini ACM, Yorio P. 1995. Distribution and abundance of seabird colonies in the Argentine sector of the Beagle Channel, Tierra del Fuego. Marine Ornithology 23: 39-46.

Sielfeld W. 1978. Prospección de Otáridos en las costas de magallanes. Anales del instituto de la Patagonia 9: 157-169.

Wünsch G. 1995. De la articulación espacial del registro arqueológico a la gestión del espacio social: un ejemplo de aplicación del análisis de las interrelaciones espaciales (Anites). In Encuentros en los conchales fueginos, Estévez J, Vila A (eds). CSICUAB: Bellaterra, Spain; 127-142. 